\title{
A similar effect of $P 16$ hydroxymethylation and true-methylation on the prediction of malignant transformation of oral epithelial dysplasia: observation from a prospective study
}

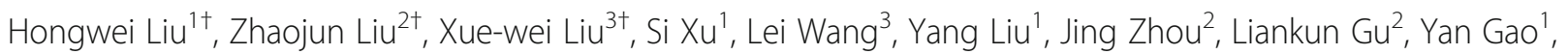
Xiao-yong Liu ${ }^{3}$, Huidong Shi ${ }^{4}$, Zheng Sun ${ }^{3^{*}}$ and Dajun Deng ${ }^{2^{*}}$ (D)

\begin{abstract}
Background: Total P16 methylation (P16M), including P16 hydroxymethylation (P16H) and true-P16M, correlates with malignant transformation of oral epithelial dysplasia (OED). Both true-P16M and P16H are early events in carcinogenesis. The aim of this study is to prospectively determine if discrimination of true-P16M from P16H is necessary for prediction of cancer development from OEDs.

Methods: Patients $(n=265)$ with mild or moderate OED were recruited into the double blind two-center cohort. Total-P16M and P16H were analyzed using the 115-bp MethyLight, TET-assisted bisulfite (TAB) methylation-specific PCR (MSP), and TAB-sequencing. Total-P16M-positive and P16H-negative samples were defined as true-P16Mpositive. Progression of OEDs was monitored for a minimum 24 months follow-up period.

Results: P16H was detected in 23 of 73 (31.5\%) total-P16M-positive OEDs. Follow-up information was obtained from 247 patients with an ultimate compliance rate of 93.2\%. OED-derived squamous cell carcinomas were observed in 13.0\% (32/247) patients during follow-up (median, 41.0 months). The cancer progression rate for totalP16M-positive patients was significantly increased when compared to total-P16M-negative patients [23.3\% vs $8.6 \%$; adjusted odds ratio $=2.67(95 \% \mathrm{Cl}: 1.19-5.99)]$. However, the cancer progression rates were similar between $\mathrm{P} 16 \mathrm{H}-$ and true-P16M-positive OEDs [26.1\% (6/23) vs 22.0\% (11/50); odds ratio = 0.80 (95\% Cl: 0.22-2.92)]. The cancer-free survival was also similar for these patients.
\end{abstract}

Conclusion: $\mathrm{P} 16 \mathrm{H}$ and true-P16M are similar biomarkers for determining malignant potential of OEDs. Discrimination of P16H from true-P16M, at least in OED, may be not necessary in clinical applications.

Trial registration: This study is registered prospectively in the U.S. National Institutes of Health Clinical Trials Protocol Registration System (trial number NCT02967120, available at https://ClinicalTrials.gov/ct2/show/ NCT02967120).

Keywords: P16, Hydroxymethylation, Oral epithelial dysplasia, Malignant transformation, Prospective cohort

\footnotetext{
* Correspondence: sunzheng12@vip.sohu.com; dengdajun@bjmu.edu.cn ${ }^{\dagger}$ Hongwei Liu, Zhaojun Liu and Xue-wei Liu contributed equally to this work. ${ }^{3}$ Capital Medical University School of Stomatology, Beijing 100050, China ${ }^{2}$ Key Laboratory of Carcinogenesis and Translational Research (MOE/Beijing), Division of Aetiology, Peking University Cancer Hospital and Institute, Beijing 100142, China

Full list of author information is available at the end of the article
}

(c) The Author(s). 2018 Open Access This article is distributed under the terms of the Creative Commons Attribution 4.0 International License (http://creativecommons.org/licenses/by/4.0/), which permits unrestricted use, distribution, and reproduction in any medium, provided you give appropriate credit to the original author(s) and the source, provide a link to the Creative Commons license, and indicate if changes were made. The Creative Commons Public Domain Dedication waiver (http://creativecommons.org/publicdomain/zero/1.0/) applies to the data made available in this article, unless otherwise stated. 


\section{Background}

Ten-eleven translocation methylcytosine dioxygenases (TET1/2/3) oxidize 5-methylcytosine $(5 \mathrm{mC})$ to 5-hydroxymethylcytosine $(5 \mathrm{hmC}), 5$-formylcytosine $(5 \mathrm{fC})$, and 5-carboxylcytosine $(5 \mathrm{caC})$ in the genome [1-4]. Although serial oxidation of $5 \mathrm{mC}$ plays a crucial role in active DNA demethylation, a proportion of $5 \mathrm{hmC}$ remains stable in the genome without subsequent oxidation and base excision, providing its own regulatory function $[5,6]$. In addition to its enrichment in the enhancer and 3 '-splice site regions of many genes, $5 \mathrm{hmC}$ also exists in $\mathrm{CpG}$ islands near the transcription start sites (TSS) of some tumor related genes [7-11]. However, the functions and potential clinical implication of the gene-specific $5 \mathrm{hmC}$ content are far from clear.

Traditional bisulfite-based analyses cannot discriminate $5 \mathrm{mC}$ from $5 \mathrm{hmC}[10,11]$. Thus, the result of DNA methylation detection using bisulfite-based methods in fact reflects total methylation, including both true methylation and hydroxymethylation. It is currently unknown whether discrimination of true methylation from hydroxymethylation in commonly used methylation assays will affect the outcome in clinical applications.

Total methylation of the promoter $\mathrm{CpG}$ island in the P16 (CDKN2A) gene (P16M) is prevalent in human cancers/precancers $[12,13]$. It has been linked to the increased cancer development from epithelial dysplasia in many organs [14-20]. True-P16M can directly inactivate gene transcription [21, 22]. We recently reported the presence of dense $5 \mathrm{hmC}$ sites in $\mathrm{P} 16$ exon- 1 regions in HCT116 cells [23, 24]. Our pilot study showed that P16 hydroxymethylation $(\mathrm{P} 16 \mathrm{H})$ also occurred in pre-cancer tissues such as oral epithelial dysplasia (OED). In contrast to true methylation of CpG islands around TSS that directly inactivates gene transcription, DNA hydroxymethylation levels are positively correlated with the transcriptional activity of genes in the mammalian genomes [9]. Here, we performed a prospective study to clarify whether the occurrence of hydroxymethylation in the P16 CpG island affects the predictability of the malignant transformation potential of OED using total-P16M as a biomarker. To the best of our knowledge, we, for the first time, report that detection of $\mathrm{P} 16 \mathrm{H}$ is not needed, since the cancer progression rates and progression-free survival are similar between true-P16M-positive $\mathrm{OED}$ and $\mathrm{P} 16 \mathrm{H}$-positive OED patients.

\section{Methods}

\section{Study design}

Two hundred sixty-five patients with mild or moderate OED were selected from cases of oral leukoplakia, lichen planus, or discoid lupus erythematosus at Peking University School of Stomatology (Center-A, $n=115$ ) and Capital Medical University School of Stomatology (Center-B, $n=150)$. The baseline OED lesions were classified as mild, moderate, or severe by at least two senior pathologists using the same criteria from the 2005 WHO Classification System as we previously reported [19]. Among these OED patients, 128 patients (66 from Center-A and 62 from Center-B) who enrolled in a previously published prospective study [19], started on February 2009 (trial number NCT01695018 at https:/ClinicalTrials.gov/ct2/show/NCT02967120; remaining blind for patients and doctors) were included in the present study, because an adequate amount of genomic DNA extracted from OED lesions was still available for the hydroxymethylation analysis. Neither doctors nor patients know the results of P16 methylation/hydroxymethylation detection during the follow-up period; and laboratory researchers do not know the patients' follow-up results during P16 methylation/ hydroxymethylation analysis. Therefore, all of these patients were recruited into the double-blind cohort study. Additional 137 OED patients were recruited from 2011 to 2015 ( $n=49$ and 88 from the Center-A and Center-B, respectively) using the same diagnosis and recruitment criteria (Fig. 1).

\section{Detection of Total-P16M and $\mathrm{P} 16 \mathrm{H}$}

To detect total-P16M, genomic DNA was extracted from frozen or formalin-fixed paraffin-embedded (FFPE) tissue samples. The proportion of the methylated copies of a 115-bp fragment in P16 exon-1 was analyzed using a modified MethyLight assay with bisulfite-modified DNA as the template $[25,26]$. Briefly, the sense-strand of the 115-bp methylated fragment in P16 exon-1 was amplified using forward primer (5'-CgCggtCgtggttagttagt-3'), reverse primer (5'-tacGctcGacGactaCgaaa-3'), and P16-specific probe (6FAM-gttgtttttCgtCgtCggtt-TAMRA). Uracil DNA glycosylase and dUTP were not added into the reaction mixture (Liu et al., 2015). A CpG island-free gene, $C O L 2 A 1$, was used as the input reference to prevent false negative detection through monitoring the amount of an input DNA template (the $\mathrm{Ct}$ value for $C O L 2 A 1 \leq 29.3$ for each included sample) as previously reported $[19,26]$.

To detect P16H, genomic DNA (3 $\mu \mathrm{g})$, spiked with both M.sssI-methylated and $5 \mathrm{hmC}$-containing $\lambda$-DNA controls (Additional file 1: Figure S1), was modified using a TET-Assisted Bisulfite (TAB) Kit according to the manufacturer's protocol (WiseGene, Cat\# K001). During the TAB modification procedures, $5 \mathrm{mC}$ was oxidized to $5 \mathrm{caC}$, and then both $5 \mathrm{caC}$ and unmethylated-cytosine were subsequently converted to uracil through bisulfite-deamination, whereas $5 \mathrm{hmC}$ was protected from oxidation through $5 \mathrm{hmC}$-specific $\beta$-glucosylation [10]. The hydroxymethylated P16 CpG 


\section{Patients with histologically proven oral OED from 2009-2011 $(n=131)$ and 2011-2015 $(n=140)$}

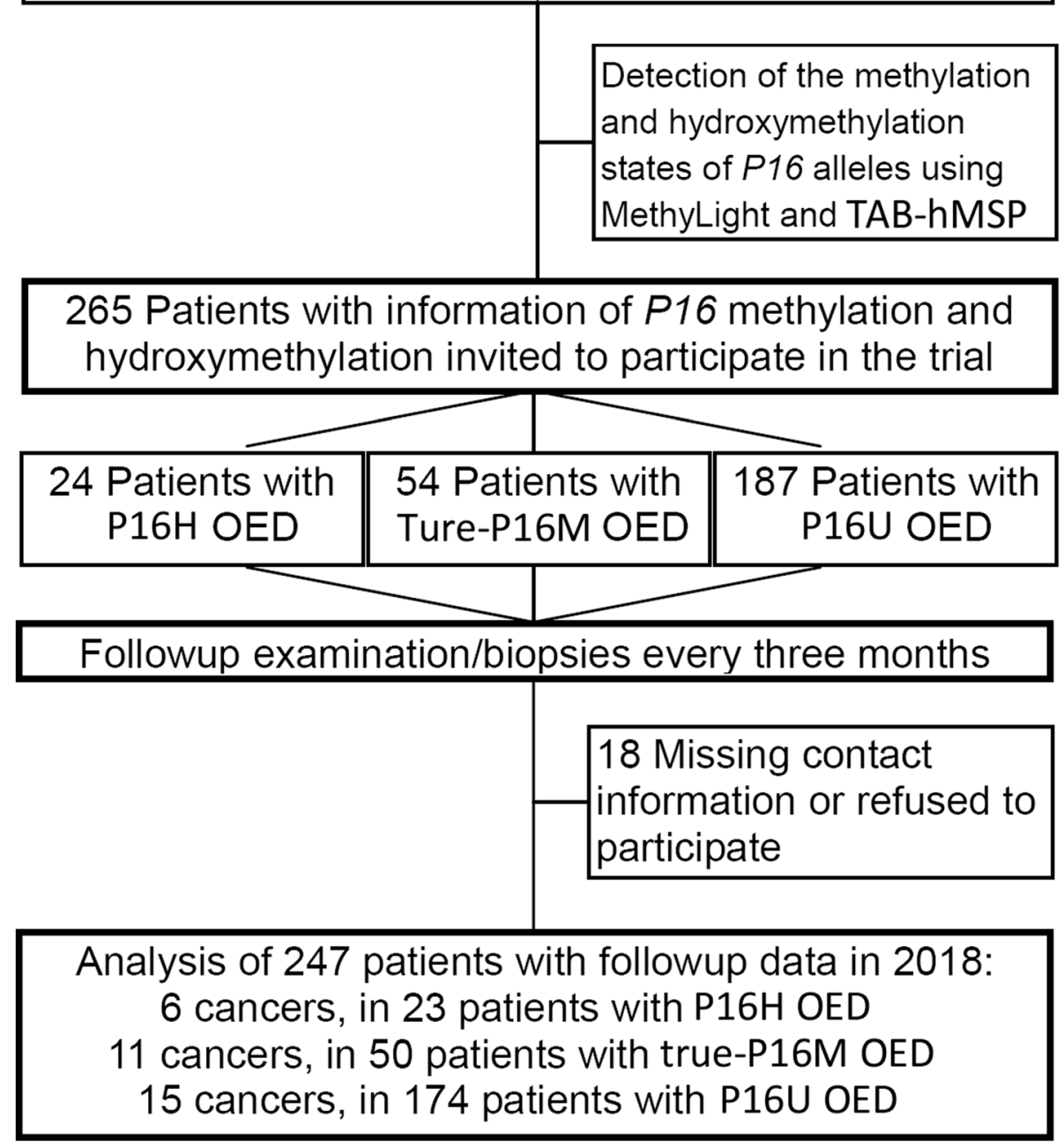

Fig. 1 Participant flow diagram. P16H, P16 hydroxymethylation-positive; True-P16M, true P16 methylation-positive; P16U, total P16 methylation-negative

island containing the glucosylated-5hmC was analyzed using TAB-modified templates and a 150-bp hydroxymethylation-specific PCR assay (TAB-hMSP). The primers for $\mathrm{P} 16 \mathrm{H}$ were 5'-ttattagagggtggggCggatCgC-3' (forward) and 5'-GaccccGaaccGcGaccGtaa-3' (reverse); the primers for non-hydroxymethylated P16 CpG islands (P16N) were 5'-tTaTTagagggtggggtggaTTgT-3' (forward) and 5'-cAaccccAaaccAcAaccAtAA-3' (reverse) [27].

To quantify the proportion of the methylated and hydroxymethylated copies of $P 16$, a 392-bp fragment of P16 exon-1 was amplified using a pair of universal primers (forward, $5^{\prime}$-tttttagaggatttgagggatagg- $3^{\prime}$ and reverse, $5^{\prime}$-ctacctaattccaattcccctacaaacttc-3') with bisulfiteand TAB-modified DNA as templates. The PCR products were analyzed using denatured high performance liquid chromatography (DHPLC) and clone-sequencing $[28,29]$.

\section{Definition of true-P16M and $\mathrm{P} 16 \mathrm{H}$ status}

As previously demonstrated, to consistently detect the fluorescence signal for total-P16M at the proportion of 1/64 (1.56\%), each MethyLight reaction (25 $\mu \mathrm{l})$ should contain at least $8 \mathrm{ng}$ bisulfite-modified template DNA to ensure that each MethyLight reaction produces an informative results $[19,26]$. When an amplification signal for the total-P16M is detected in an informative sample, the sample is defined as total-P16M-positive; otherwise, it is considered as total-P16M-negative. Based on the results from TAB-hMSP, the total-P16M-positive samples were further sub-classified into 
hydroxymethylation-positive (P16H) and true-P16Mpositive samples, respectively.

\section{Follow-up examination and histopathology}

The follow-up examination was carried out in a double blind fashion as previously described [19]. If malignant development was observed, an additional examination and re-biopsy were carried out. OED-derived oral squamous cell cancer (OSCC) was histopathologically diagnosed.

\section{Statistical analysis}

Results were displayed by the constituent ratios of enumeration or ranked data. Univariate and multivariate analyses were performed using the Chi Square test and binary logistic regression analysis in SPSS16.0 software. Student's $t$-test was used to analyze the age data. Patient cancer-free survival was analyzed using the Kaplan-Meier method and log-rank test. Cox's proportional hazard model was used for multivariate analyses. All $P$-values were two-sided, and $P<0.05$ was considered statistically significant.

\section{Results}

\section{Patients' basic information}

Of the baseline mild and moderate OED patients $(n=$ 265), 18 cases were lost during the follow-up due to changes to contact information. Thus, 247 cases with follow-up information were ultimately enrolled into the final cohort analysis giving an overall compliance rate of 93.2\% (Fig. 1). 73 OEDs were total-P16M-positive; and among them, 23 were $\mathrm{P} 16 \mathrm{H}$-positive. No significant difference in average age, sex ratio, alcohol drinking status, occurrence of Lichen Planus, and lesion grade was observed between total-P16M-positive and -negative OED patients $(P>0.05)$. The proportion of patients with cigarette smoking history was significantly higher in the
total-P16M-negative group than the total-P16M-positive group $(33.3 \%$ vs $17.8 \%, P=0.014$; Table 1$)$. The proportion of patients with tongue OED was significantly lower in the total-P16M-negative group than the total-P16M-positive group ( $39.1 \%$ vs $56.2 \%, P=0.017)$.

\section{A similar effect of true-P16M and P16H on predicting malignant progression of oral epithelial dysplasia} Malignant transformation of OED to OSCC was observed in 32 of 247 (13.0\%) patients during follow-up (range, 14 to 129 months; median, 41.0 months). The average baseline age of patients who underwent malignant progression was 3.1 yrs. older than that of patients who remained stable, but not statistically significant (59.3 yrs. vs. 56.2 yrs., $P=0.103$ ). The OED lesions of the tongue showed a significantly higher rate of cancer progression than those at other sites $(22.0 \%$ vs $5.8 \%, P<0.001)$.

The progression rate of OED to OSCC in the 73 total-P16M-positive patients was consistently higher than that of the 174 total-P16M-negative (P16U) patients when analyzing different subgroups including: sex, age, baseline grade, lesion site, center/hospital, and specimen storage medium, etc. (Table 2). Multivariate analysis showed that the risk of malignant transformation for total-P16M-positive OEDs was significantly higher than that of total-P16M-negative (P16U) OEDs after adjusting for age, sex, cigarette smoking, alcohol drinking, lesion site, and OED grade [23.3\% vs. $8.6 \%$; adjusted odds ratio $=2.67$, 95\% confidence interval $(\mathrm{CI})$ : 1.19 5.99] (Table 2).

Most importantly, among the 73 total-P16M-positive patients, the cancer progression rate between OED patients with and without $\mathrm{P} 16 \mathrm{H}$ was not different $[26.1 \%$ $(6 / 23)$ vs. $22.0 \%$ (11/50); odds ratio $=0.80$ (95\% CI: $0.22-$ 2.92)] (Fig. 2a). Kaplan-Meier analysis also showed that the cancer-free survival curves were similar between

Table 1 Clinical characteristics of patients with oral epithelial dysplasia enrolled into the final follow-up analysis

\begin{tabular}{|c|c|c|c|c|c|}
\hline \multirow{2}{*}{$\begin{array}{l}\text { Status of P16 methylation and hydroxymethylation } \\
\text { Subgroup }\end{array}$} & \multirow{2}{*}{$\begin{array}{l}\text { Total-P16M- negative } \\
\text { (P16U) }\end{array}$} & \multicolumn{3}{|c|}{ Total-P16M-positive } & \multirow[t]{2}{*}{ Total } \\
\hline & & (All) & True-P16M & $\mathrm{P} 16 \mathrm{H}$ & \\
\hline Case number & 174 & 73 & 50 & 23 & 247 \\
\hline Age (yrs, mean $\pm S D)$ & $55.9 \pm 10.3$ & $58.1 \pm 9.7$ & $59.3 \pm 9.4$ & $55.4 \pm 10.1$ & $56.6 \pm 10.2$ \\
\hline Sex ratio (male, \%) & 48.3 & 38.4 & 36.0 & 43.5 & 45.3 \\
\hline Cigarette smoking (yes, \%) & $\underline{33.3}$ & $\underline{17.8}^{\mathrm{a}}$ & 22.0 & 8.7 & 28.7 \\
\hline Alcohol drinking (yes, \%) & 24.1 & 19.2 & 18.0 & 21.7 & 22.7 \\
\hline Baseline grade (mild, \%) & 69.5 & 58.9 & 58.0 & 60.9 & 59.9 \\
\hline Lesion site (tongue, \%) & 39.1 & $\underline{56.2}^{\mathrm{b}}$ & 54.0 & 60.9 & 44.1 \\
\hline Oral Leukoplakia (\%) & 69.1 & 30.9 & 21.7 & 9.2 & $(n=217)$ \\
\hline Oral Lichen Planus (\%) & 79.3 & 20.7 & 10.3 & 10.3 & $(n=29)$ \\
\hline Discoid lupus erythematous & 1 & 0 & 0 & 0 & $(n=1)$ \\
\hline
\end{tabular}

$\overline{a / b}$ Fish exact-test, $\mathrm{P} 16 \mathrm{U}$ vs total-P16M-positive (All): $P=0.014 / 0.017$ 
Table 2 Comparison of malignant transformation of total P16 methylation-positive and -negative oral epithelial dysplasia in patients with various baseline clinicopathological characteristics

\begin{tabular}{|c|c|c|c|c|c|c|c|c|}
\hline \multirow[t]{2}{*}{ Item } & \multicolumn{3}{|c|}{ All cases } & \multicolumn{2}{|c|}{ Total-P16M -negative (P16U) } & \multicolumn{2}{|c|}{ Total-P16M -positive } & \multirow{2}{*}{$\begin{array}{l}\text { Odd ratio }(95 \% \\
\mathrm{Cl}) \text { in univariate } \\
\text { analysis }\end{array}$} \\
\hline & $n$ & Total-P16M-positive rate (\%) & Cancer rate $(\%)$ & $n$ & Cancer cases (\%) & $n$ & Cancer cases \%) & \\
\hline \multicolumn{9}{|l|}{ Sex } \\
\hline Male & 112 & 25.0 & 8.9 & 84 & $5(6.0)$ & 28 & $5(17.9)$ & \\
\hline Female & 135 & 33.3 & 16.3 & 90 & $10(11.1)$ & 45 & $12(26.7)$ & $2.91(1.15-7.39)$ \\
\hline \multicolumn{9}{|l|}{ Age (yrs) } \\
\hline$<60$ & 153 & 26.8 & 11.8 & 112 & $9(8.0)$ & 41 & $9(22.0)$ & $3.22(1.18-8.80)$ \\
\hline$\geq 60$ & 94 & 34.0 & 14.9 & 62 & $6(9.7)$ & 32 & $8(25.0)$ & \\
\hline \multicolumn{9}{|c|}{ Cigarette smoking } \\
\hline Yes & 71 & 18.3 & 8.5 & 58 & $4(6.9)$ & 13 & $2(15.4)$ & \\
\hline No & 176 & 34.1 & 14.8 & 116 & $11(9.5)$ & 60 & $15(25.0)$ & $3.18(1.36-7.47)$ \\
\hline \multicolumn{9}{|c|}{ Alcohol drinking } \\
\hline Yes & 56 & 25.0 & 8.9 & 42 & $2(4.8)$ & 14 & $3(21.4)$ & \\
\hline No & 191 & 30.9 & 14.1 & 132 & $13(9.8)$ & 59 & $14(23.7)$ & $2.85(1.24-6.53)$ \\
\hline \multicolumn{9}{|c|}{ Lesion grade } \\
\hline Mild & 164 & 26.2 & 11.6 & 121 & $10(8.3)$ & 43 & $9(20.9)$ & $2.94(1.10-7.82)$ \\
\hline Mod. & 83 & 36.1 & 15.7 & 53 & $5(9.4)$ & 30 & $8(26.7)$ & $3.49(1.02-11.90)$ \\
\hline \multicolumn{9}{|l|}{ Lesion site } \\
\hline Tongue & 109 & 37.6 & $\underline{22.0}^{a, c}$ & 68 & $9(13.2)$ & 41 & 15 (36.6) & 3.78 (1.47-9.75) \\
\hline Others & 138 & 23.2 & $\underline{5.8}$ & 106 & $6(5.7)$ & 32 & $2(6.3)$ & \\
\hline \multicolumn{9}{|l|}{ Center } \\
\hline A & 112 & 33.0 & 11.6 & 75 & $6(8.0)$ & 37 & $7(18.9)$ & \\
\hline B & 135 & 26.7 & 14.1 & 99 & $9(9.1)$ & 36 & $10(27.8)$ & $3.85(1.41-10.46)$ \\
\hline \multicolumn{9}{|c|}{ Sample storage } \\
\hline Frozen & 87 & 32.2 & 12.6 & 59 & $5(8.5)$ & 28 & $6(21.4)$ & \\
\hline Paraffin & 160 & 28.1 & 13.1 & 115 & $10(8.7)$ & 45 & $11(24.4)$ & $3.40(1.33-8.69)$ \\
\hline Total & 247 & 29.6 & 13.0 & 174 & $15(8.6)$ & 73 & $17(23.3)$ & $3.22(1.51-6.87) b$ \\
\hline
\end{tabular}

${ }^{a}$ Tongue vs Other, $P<0.001 ;{ }^{b}$ Total-P16M-negative vs Total-P16M-positive, $P=0.002 ;{ }^{c / d}$ Adjusted-odds ratio: $0.22(0.09-0.55) / 2.67$ (1.19-5.99), respectively, after sex, age, smoking, alcohol use, lesion site, and lesion grade were adjusted in multivariate analysis. The values are presented in the bold letters when difference between two subgroups is statistically significant.

these OED patients with and without $\mathrm{P} 16 \mathrm{H}$, though statistically significant differences were observed between the total-P16M-negative (P16U) and total-P16M-positive patients (log-rank test, $P=0.001$; adjusted hazard ratio $=$ 2.21, 95\% CI: 1.08-4.54; Fig. 2b).

\section{Characterization of methylated- and Hydroxymethylated- P16 alleles in OED}

The hydroxymethylation and methylation states of the P16 exon-1 region were further determined using DHPLC in three representative samples. The DHPLC results showed that the retention time for total-P16M was longer than that of $\mathrm{P} 16 \mathrm{H}$ for Sample-A and -B (Fig. 3a), suggesting that there were more unconverted $\mathrm{CpGs}$ in the bisulfite-treated P16 exon-1 templates than that of the TAB-treated templates. Clone sequencing further confirmed the DHPLC results. As shown in Fig. 3b, both the bisulfite-sequencing and $\mathrm{TAB}$-sequencing results revealed consecutive unconverted $\mathrm{CpGs}$ in some alleles in both Sample-A and -B. Interestingly, CpGs \# 27-31 were not hydroxylmethylated in these two samples analyzed. The sequencing results also show that only some alleles are densely methylated, indicate partial methylation in these samples. However, the proportion of alleles with unconverted CpGs was higher in bisulfite-sequencing results than that of TAB-sequencing results, suggesting that the $5 \mathrm{hmCs}$ were indeed measured in the bisulfite-sequencing and contributed to the total P16M level.

\section{Discussions}

Numerous studies have demonstrated great potentials of using gene-specific DNA methylation changes as biomarkers for early detection of cancer, diagnosis and 

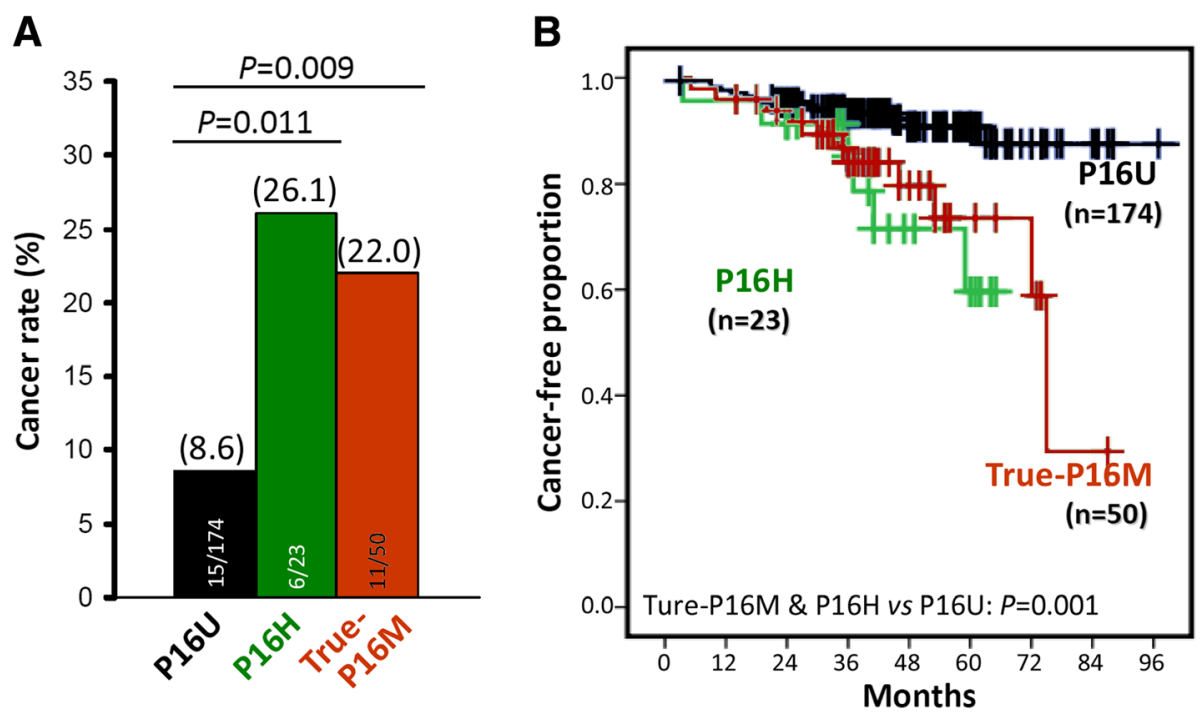

Fig. 2 Comparison of the cancer rates of oral epithelial dysplasia (OED) patient groups based on the P16 alleles with various methylation and hydroxymethylation states. a OED-derived cancer rate (\%); b Estimated cancer-free survival curves in Kaplan-Meier analysis ( $P<0.001)$

prognosis of cancer, and predicting chemotherapy sensitivity and drug resistance. DNA methylation markers may be better suited in clinical oncology practice due to its high sensitivity of detection, high stability in the genome, and relatively low requirements for sample storage [30, 31]. For example, Sept9 methylation is used as a biomarker for colorectal cancer screening, MGMT methylation is used for predicting sensitivity of gliomas to alkylating agents, and DNA methylation panel is used to characterize tissue origin of un-identified cancers $[32,33]$. In contract to DNA methylation that stably represses gene transcription, occurrence of $5 \mathrm{hmC}$ is positively associated with upregulation of gene transcription [9]. It is likely that DNA hydroxymethylation functions oppositely relative to DNA true methylation in regulation of gene transcription. Therefore, it remains unknown whether occurrence of $5 \mathrm{hmC}$ in gene regulatory regions interferences the clinical usages of DNA methylation markers, or whether it is necessary to differentiate DNA true methylation from hydroxymethylation. In the present prospective study we have found, for the first time, that $\mathrm{P} 16 \mathrm{H}$ presents in $31.5 \%$ $(23 / 73)$ of total-P16M-positive OED samples and that occurrence of $5 \mathrm{hmC}$ in the P16 CpG islands has no impact on prediction of OED malignant transformation using total-P16M as a biomarker.

Our nested case-control and prospective cohort studies as well as similar studies by others consistently prove that total-P16M is associated with a higher risk of malignant transformation of precancer mucosal epithelial dysplasia in many organs, including oral cavity, esophagus, lung, and stomach [14-20]. The results of present study further confirmed this observation.
We recently found that dense $5 \mathrm{hmC}$ sites within methylated-P16 exon-1 CpG islands in cancer cells may play a role in homeostatic maintenance of methylation of P16 CpG islands [23]. Unexpectedly, results of the present study did not show detectable difference in OED-derived cancer rate or cancer-free survival between true-P16M-positive OED patients and P16H-positive OED patients. Because the final amount of TAB-template was very limited for most of samples, detection of the $\mathrm{P} 16 \mathrm{H}$ proportion in total-P16M-positive samples by MethyLight is not performed. Therefore, it is unknown whether the $\mathrm{P} 16 \mathrm{H}$-positive samples also contain true-P16M. The representative bisulfite- and TAB-sequencing results seem to suggest that $5 \mathrm{hmC}$ was only a portion of total $5 \mathrm{mC}$ measured by conventional bisulfite-sequencing, though the sequencing results are not very quantitative due to the limited number of clones sequenced.

Our recent study revealed that hydroxymethylated-P16 alleles in HCT116 cells were transcriptionally inactive [23]. To further study whether hydroxymethylation of the P16 CpG islands affects gene transcription, we engineered an expression controllable P16-specific dioxygenase (P16-TET) and found that DNA demethylation via hydroxymethylation by P16-TET, but not hydroxymethylation itself, could reactivate transcription of methylated P16 alleles in cancer cells (Gan et al., prepared for publication). These findings suggest that both truly methylated- and hydroxymethylated P16 alleles are transcriptionally inactive. The results of the present prospective cohort study are consistent with these findings.

P16 methylation directly inactivates gene transcription and promotes the invasion of cancer cells [21]. Loss of 


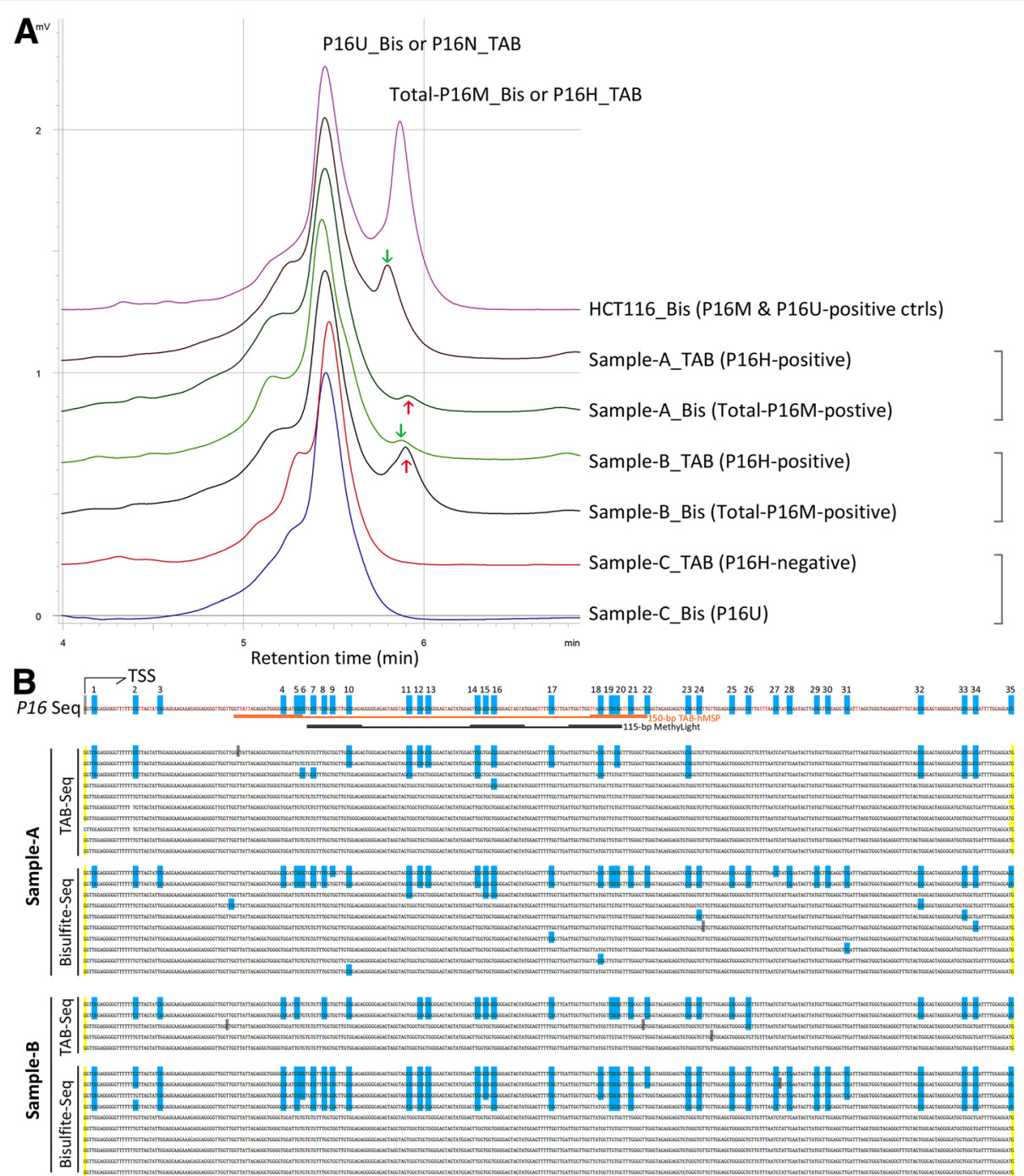

Fig. 3 Characterization of the methylation and hydroxymethylation states of CpG sites in a 392-bp fragment of P16 exon-1 in representative OED samples. a DHPLC chromatogram of total-P16M (red arrow-pointed) and total-P16U PCR products amplified from regular bisulfite-templates (Bis); or P16H (green arrow-pointed) and non-hydroxymethylated-P16 (P16N) PCR products amplified from TAB-templates (TAB). P16 hemi-methylated cell line HCT116 was used as standard control; Sample-C was total-P16M-negative and P16H-negative; $\mathbf{b}$ Results of TAB-sequencing and bisulfitesequencing for two representative total-P16M-positive and P16H-positive samples, respectively; each line represents one clone; blue-dot, methylated or hydroxymethylated CpG site; \#1-35, CpG ID; location of the 115-bp MethyLight amplicon and the 150-bp TAB-hMSP amplicon were also indicated

function of P16 results in higher cyclin D-dependent protein kinase (CDK4/6) activity and thus leads to aberrant phosphorylation of retinoblastoma (RB), which accelerates cell growth. Germline P16 inactivation by point mutations leads to familial melanoma [34-36]. Both true-P16M and $\mathrm{P} 16 \mathrm{H}$ cause P16 inactivation, this may account for the increase risk of malignant transformation of total-P16M-positive OED lesions.

It was reported that malignant transformation rates for OED patients with and without total-P16M were $27.1 \%$ and $8.6 \%$ in a double-blind mutiplecentre prospective study [19]. The malignant transformation rates in the present study were very similar to those: $23.3 \%$ and $8.6 \%$ for OED patients with and without total-P16M. Because 128 OED patients were enrolled in both studies and only 137 additional OED patients were recruited into the two-center study, this may partially account for the similarity.

\section{Conclusions}

Total-P16M, including true- $\mathrm{P} 16 \mathrm{M}$ and $\mathrm{P} 16 \mathrm{H}$, is consistently and significantly linked to malignant transformation of epithelial dysplasia, as previously reported. It is unknown whether or not discrimination of true methylation from hydroxymethylation of P16 CpG islands is essential in clinical applications. In the present prospective 


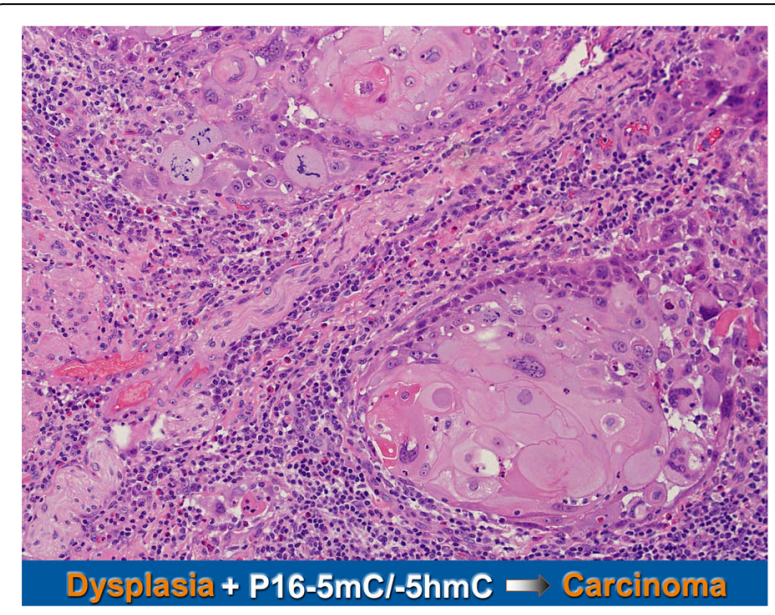

Fig. 4 Illustration of both P16 methylation and hydroxymethylation increase cancer risk of OED

study, we found, for the first time, that cancer risks may not be different between total-P16M-positive OED patients with and without P16H (Fig. 4). Therefore, descrimination of DNA hydroxymethylation from true methylation is not necessary, when total-P16M is used as a biomarker to detect the cancer risk of precancerous lesions.

\section{Additional file}

Additional file 1: Figure S1. Characterization of the true methylation and hydroxymethylation states of $\mathrm{CpG}$ sites in the M.sssl-methylated and $5 \mathrm{hmC}$-containing $\lambda$-DNA controls (5mC-Ctrl and $5 \mathrm{hmC}$-Ctrl). Bisulfitemodified DNA templates were used to discriminate $5 \mathrm{mC}$ or $5 \mathrm{hmC}$ from unmethylated cytosine. TAB-modified DNA templates were used to discriminate $5 \mathrm{hmC}$ from $5 \mathrm{mC}$ or unmethylated cytosine. The $\mathrm{CpG}$ sites within the consensus sequences were listed above the corresponding clone sequences. The number of $5 \mathrm{hmC}$ or $5 \mathrm{mC}$ sites within each clone was also listed on the left side. These control DNA was added into test samples to monitor the conversion status of $5 \mathrm{mC}, 5 \mathrm{hmC}$, and unmethylated-cytosine in genomic DNA by bisulfite and TAB treatments. (TIF $197 \mathrm{~kb})$

\section{Abbreviations}

Bis: Bisulfite modification; DHPLC: Denatured high performance liquid chromatography analysis; hMSP: Hydroxymethylation-specific PCR; OED: Oral epithelial dysplasia; P16H: P16 hydroxymethylated; P16M: P16 methylation; P16N: P16 not hydroxymethylated; P16U: P16 not methylated; TAB: TETassisted bisulfite modification

\section{Funding}

This work was supported by Beijing Municipal Administration of Hospital Clinical Medical Development of Special Funding Support (XM201303), National Natural Science Foundation of China (81672770), and Beijing Science and Technology Commission (Z151100001615022) to DD. The funding agencies have no role in the actual experimental design, patient recruitment, data collection, analysis, interpretation, or writing of this manuscript.

\section{Availability of data and materials}

This study is registered in the U.S. National Institutes of Health Clinical Trials Protocol Registration System in accordance with the criteria outlined by the International Committee of Medical Journal Editors (trial number
NCT02967120, available at http://ClinicalTrials.gov). The registration date was November 17, 2016.

\section{Authors' contributions}

HL, X-WL, SX, LW, YL, ZS collected patients' tissue samples and follow-up data; $Y G$ and $X$-yL performed histological examinations of oral biopsies. JZ and LG extracted genomic DNA. ZL analyzed the methylation and hydroxymethylation status of P16 CpG islands and association of P16 DNA modifications with cancer risk of OED. DD designed the follow-up study, analyzed the data, and was the major contributor in writing the manuscript. HS edited the manuscript proof. All authors have read and commented on the manuscript and approved the final version.

\section{Ethics approval and consent to participate}

The Institutional Review Boards of the Peking University Cancer Hospital approved this study. All patients gave written informed consent.

\section{Consent for publication}

Not applicable.

\section{Competing interests}

The authors declare that they have no competing interests.

\section{Publisher's Note}

Springer Nature remains neutral with regard to jurisdictional claims in published maps and institutional affiliations.

\section{Author details}

${ }^{1}$ Key Laboratory of Carcinogenesis and Translational Research (Ministry of Education/Beijing), Peking University School of Stomatology, Beijing 100081, China. ${ }^{2}$ Key Laboratory of Carcinogenesis and Translational Research (MOE/ Beijing), Division of Aetiology, Peking University Cancer Hospital and Institute, Beijing 100142, China. ${ }^{3}$ Capital Medical University School of Stomatology, Beijing 100050, China. ${ }^{4}$ Georgia Cancer Center, Medical College of Georgia, Augusta University, Augusta, GA 30912, USA.

Received: 12 March 2018 Accepted: 31 August 2018 Published online: 24 September 2018

\section{References}

1. Tahiliani M, Koh KP, Shen Y, Pastor WA, Bandukwala H, Brudno Y, Agarwal S, lyer LM, Liu DR, Aravind L, Rao A. Conversion of 5-methylcytosine to 5hydroxymethylcytosine in mammalian DNA by MLL partner TET1. Science. 2009;324:930-5.

2. Kriaucionis S, Heintz N. The nuclear DNA base 5-hydroxymethylcytosine is present in Purkinje neurons and the brain. Science. 2009:324:929-30.

3. He YF, Li BZ, Li Z, Liu P, Wang Y, Tang Q, Ding J, Jia Y, Chen Z, Li L, Sun Y, Li $X$, et al. Tet-mediated formation of 5-carboxylcytosine and its excision by TDG in mammalian DNA. Science. 2011;333:1303-7.

4. Ito S, Shen L, Dai Q, Wu SC, Collins LB, Swenberg JA, He C, Zhang Y. Tet proteins can convert 5-methylcytosine to 5-formylcytosine and 5carboxylcytosine. Science. 2011;333:1300-3.

5. Gu TP, Guo F, Yang H, Wu HP, Xu GF, Liu W, Xie ZG, Shi L, He X, Jin SG, lqbal K, Shi YG, et al. The role of Tet3 DNA dioxygenase in epigenetic reprogramming by oocytes. Nature. 2011:477:606-10.

6. Williams K, Christensen J, Pedersen MT, Johansen JV, Cloos PA, Rappsilber J, Helin K. TET1 and hydroxymethylcytosine in transcription and DNA methylation fidelity. Nature. 2011:473:343-8.

7. Hackett JA, Sengupta R, Zylicz JJ, Murakami K, Lee C, Down TA, Surani MA. Germline DNA demethylation dynamics and imprint erasure through 5hydroxymethylcytosine. Science. 2013;339:448-52.

8. Pastor WA, Pape UJ, Huang Y, Henderson HR, Lister R, Ko M, McLoughlin EM, Brudno Y, Mahapatra S, Kapranov P, Tahiliani M, Daley GQ, et al. Genome-wide mapping of 5-hydroxymethylcytosine in embryonic stem cells. Nature. 2011;473:394-7.

9. Ficz G, Branco MR, Seisenberger S, Santos F, Krueger F, Hore TA, Marques CJ, Andrews S, Reik W. Dynamic regulation of 5-hydroxymethylcytosine in mouse ES cells and during differentiation. Nature. 2011;473:398-402.

10. Song CX, Szulwach KE, Fu Y, Dai Q, Yi C, Li X, Li Y, Chen CH, Zhang W, Jian $X$, Wang J, Zhang $L$, et al. Selective chemical labeling reveals the genomewide distribution of 5-hydroxymethylcytosine. Nat Biotechnol. 2011;29:68-72. 
11. Yu M, Hon GC, Szulwach KE, Song CX, Zhang L, Kim A, Li X, Dai Q, Shen Y, Park B, Min JH, Jin P, et al. Base-resolution analysis of 5hydroxymethylcytosine in the mammalian genome. Cell. 2012;149:1368-80.

12. Merlo A, Herman JG, Mao L, Lee DJ, Gabrielson E, Burger PC, Baylin SB, Sidransky D. 5' CPG island methylation is associated with transcriptional silencing of the tumor-suppressor P16/CDKN2/MTS1 in human cancers. Nat Med. 1995;1:686-92.

13. Herman JG, Merlo A, Mao L, Lapidus RG, Issa JPJ, Davidson NE, Sidransky D, Baylin SB. Inactivation of the Cdkn2/P16/Mts1 gene is frequently associated with aberrant Dna methylation in all common human cancers. Cancer Res. 1995:55:4525-30.

14. Sun Y, Deng DJ, You WC, Bai H, Zhang L, Zhou J, Shen L, Ma JL, Xie YQ, Li JY. Methylation of p16 CpG islands associated with malignant transformation of gastric dysplasia in a population-based study. Clin Cancer Res. 2004;10:5087-93.

15. Belinsky SA, Liechty KC, Gentry FD, Wolf HJ, Rogers J, Vu K, Haney J, Kennedy TC, Hirsch FR, Miller Y, Franklin WA, Herman JG, et al. Promoter hypermethylation of multiple genes in sputum precedes lung cancer incidence in a high-risk cohort. Cancer Res. 2006;66:3338-44.

16. Hall GL, Shaw RJ, Field EA, Rogers SN, Sutton DN, Woolgar JA, Lowe D, Liloglou T, Field JK, Risk JM. p16 promoter methylation is a potential predictor of malignant transformation in oral epithelial dysplasia. Cancer Epidemiol Biomark Prev. 2008;17:2174-9.

17. Cao J, Zhou J, Gao Y, Gu L, Meng H, Liu H, Deng D. Methylation of p16 CpG Island associated with malignant progression of oral epithelial dysplasia: a prospective cohort study. Clin Cancer Res. 2009;15:5178-83.

18. Jin Z, Cheng Y, Gu W, Zheng Y, Sato F, Mori Y, Olaru A, Paun B, Yang J, Kan T, Ito T, Hamilton J, et al. A multicenter, double-blinded validation study of methylation biomarkers for progression prediction in Barrett's esophagus. Cancer Res. 2009;69:4112-5.

19. Liu HW, Liu XW, Dong GY, Zhou J, Liu Y, Gao Y, Liu XY, Gu LK, Sun Z, Deng DJ. P16 methylation as an early predictor for Cancer development from oral epithelial dysplasia: a double-blind multicentre prospective study. EBioMedicine. 2015;2:6

20. Gao H, Zhang Y, Zhou J, Li Z, Ma JL, Liu WD, Deng DJ, You WC, Pan KF. Association between p16 methylation and malignant transformation of gastric dysplasia. Chin J Cancer Prev Treat. 2017;24:6.

21. Cui C, Gan Y, Gu L, Wilson J, Liu Z, Zhang B, Deng D. P16-specific DNA methylation by engineered zinc finger methyltransferase inactivates gene transcription and promotes cancer metastasis. Genome Biol. 2015;16:252.

22. Gan Y, Ma W, Wang X, Qiao J, Zhang B, Cui C, Liu Z, Deng D. Coordinated transcription of ANRIL and P16 genes is silenced by P16 DNA methylation. Chin J Cancer Res. 2018:30:93-103.

23. Qin SS, Li Q, Zhou J, Liu ZJ, Su N, Wilson J, Lu ZM, Deng DJ. Homeostatic maintenance of allele-specific p16 methylation in Cancer cells accompanied by dynamic focal methylation and Hydroxymethylation. PLoS One. 2014;9:E97785.

24. Qin S, Zhang B, Tian W, Gu L, Lu Z, Deng D. Kaiso mainly locates in the nucleus in vivo and binds to methylated, but not hydroxymethylated DNA. Chin J Cancer Res. 2015;27:148-55.

25. Zhou J, Cao J, Lu Z, Liu H, Deng D. A 115-bp MethyLight assay for detection of p16 (CDKN2A) methylation as a diagnostic biomarker in human tissues. Bmc Med Genet. 2011;12:67.

26. Liu Z, Zhou J, Gu L, Deng D. Significant impact of amount of PCR input templates on various PCR-based DNA methylation analysis and countermeasure. Oncotarget. 2016;7:56447-55.

27. Herman JG, Graff JR, Myöhänen S, Nelkin BD, Baylin SB. Methylation-specific PCR: a novel PCR assay for methylation status of CpG islands. Proc Natl Acad Sci U S A. 1996;93:9821-6.

28. Deng DJ, Deng GR, Smith MF, Zhou J, Xin HJ, Powell SM, Lu YY. Simultaneous detection of CpG methylation and single nucleotide polymorphism by denaturing high performance liquid chromatography. Nucleic Acids Res. 2002;30:13E.

29. Luo DY, Zhang BZ, Lv LB, Xiang SY, Liu YH, Ji JF, Deng DJ. Methylation of CpG islands of p16 associated with progression of primary gastric carcinomas. Lab Investig. 2006:86:591-8.

30. Deng D, Liu Z, Du Y. Epigenetic alterations as Cancer diagnostic, prognostic, and predictive biomarkers. In: Herceg Z, Ushijima T Epigenetics and Cancer, Pt Bed, vol. 71, 2010: 125-76.

31. Deng DJ, Lu ZM. Differentiation and Adaptation epigenetic networks: translational research in gastric carcinogenesis. Chin Sci Bull. 2013:58:1-6.
32. Guo S, Diep D, Plongthongkum N, Fung HL, Zhang K. Identification of methylation haplotype blocks aids in deconvolution of heterogeneous tissue samples and tumor tissue-of-origin mapping from plasma DNA. Nat Genet. 2017:49:635-42.

33. Moran S, Martinez-Cardús A, Boussios S, Esteller M. Precision medicine based on epigenomics: the paradigm of carcinoma of unknown primary. Nat Rev Clin Oncol. 2017;14:682-94

34. Liu L, Lassam NJ, Slingerland JM, Bailey D, Cole D, Jenkins R, Hogg D. Germline p16INK4A mutation and protein dysfunction in a family with inherited melanoma. Oncogene. 1995;11:405-12.

35. Hussussian CJ, Struewing JP, Goldstein AM, Higgins PA, Ally DS, Sheahan MD, Clark WH Jr, Tucker MA, Dracopoli NC. Germline p16 mutations in familial melanoma. Nat Genet. 1994;8:15-21.

36. Kannengiesser C, Brookes S, del Arroyo AG, Pham D, Bombled J, Barrois M, Mauffret O, Avril MF, Chompret A, Lenoir GM, Sarasin A, French hereditary melanoma study group, Peters G, Bressac-de Paillerets B. Functional, structural, and genetic evaluation of 20 CDKN2A germ line mutations identified in melanoma-prone families or patients. Hum Mutat. 2009;30:564-74.

\section{Ready to submit your research? Choose BMC and benefit from:}

- fast, convenient online submission

- thorough peer review by experienced researchers in your field

- rapid publication on acceptance

- support for research data, including large and complex data types

- gold Open Access which fosters wider collaboration and increased citations

- maximum visibility for your research: over $100 \mathrm{M}$ website views per year

At BMC, research is always in progress.

Learn more biomedcentral.com/submissions 